\title{
EDITORIAL
}

\section{EL PANORAMA JURÍDICO HACIA FINES DEL AÑO 2007}

El fin del año calendario y, en nuestro caso, académico, invariablemente demanda hacer reflexiones acerca de los avances y rasgos más característicos que pueden reconocerse en el período correspondiente.

Sin duda, en esa perspectiva, el año 2007 ha sido en Chile uno de aquellos caracterizados, en lo constructivo, por un importante desarrollo jurídico de temas ya clásicos del Derecho y también por la creciente innovación en temáticas atractivas y desafiantes, en las cuales los juristas han de acercarse al trabajo interdisciplinario y a la creación de fórmulas omnicomprensivas para abordar realidades tales como la creación de nuevos modelos contractuales, la diversificación de las posibilidades económicas y comerciales, la evolución de los tipos penales, la modernización de los procedimientos y la conceptualización de nuevos derechos desde la óptica garantista.

Sin embargo, también este año ha tenido una faz agonal. No podemos ignorar el creciente conflicto en los puntos de inflexión entre lo público y lo privado -lo cual alcanza desde los estatutos concesionales hasta el régimen tributario, pasando por la legislación sobre acceso a la información pública-, los dilemas valóricos que se proyectan sin duda al escenario de los derechos y de las facultades de los órganos del Estado y, por supuesto, la evidencia que en materia judicial no basta examinar el contenido de los fallos, sino que es cada vez más importante cómo se dictan y cuándo tarda en ellos la magistratura, qué posibilidades tienen las partes de hacer valer sus pretensiones en el proceso y cómo se evitan los desequilibrios naturales propios de muchas situaciones judicializadas.

Esa diversidad que importa, a un mismo tiempo, construcción, conflicto y desafío, ha sido recogida en valiosas contribuciones de nuestros autores en los tres números de este año, en que no ha estado ausente la interpretación del Derecho, su aplicación a una casuística muy variada, la crítica de situaciones que parecen poco razonables y -sobre todo- mejorables, y el debate académico, en el mundo del encuentro y confrontación de las ideas y no de las personas.

Estamos conscientes que el Derecho chileno, en algunos aspectos, se encuentra en vías de tratar de un modo objetivo ciertas situaciones fácticas que ya se conocen desde hace mucho tiempo en otros países y que requieren una normativización de acuerdo a nuestra cultura, valores y necesidades, lo que no es fácil; pero también y con satisfacción, nos damos cuenta que la doctrina nacional, la jurisprudencia de nuestros tribunales y la fructífera producción de otras entidades generadoras de normas o sentencias brindan bases jurídicas que, con una correcta orientación, se acercarán a un resultado de justicia.

Esa tarea de compatibilización, como es obvio, tiene o implica dificultades y hemos buscado que la Revista Chilena de Derecho se constituya en un aporte en tal sentido y en una fuente en la cual muchas de las inquietudes que el panorama legal y 
judicial de nuestro país nos genera, tengan modo de encauzarse y de encontrar bases de diálogo y fuentes de apoyo.

Deseamos a todos nuestros lectores una feliz Navidad y, para todos, la posibilidad de seguirnos encontrando el año 2008 en estas páginas con redoblados esfuerzos, con interesantes novedades y, sobre todo, con la aspiración compartida de un escenario de resguardo de la dignidad, protección de las personas y eficiencia de los instrumentos que nuestro Derecho crea para ello.

ÁngEla ViVAnCo MARTíneZ

Directora

Revista Chilena de Derecho 